JURNAL SEKRETARIS \& ADMINISTRASI BISNIS

Jumal homepage hittp /jurnal asmtb actid/index php/jsab

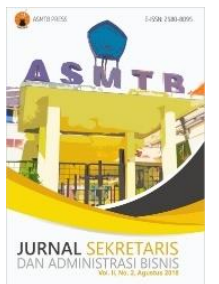

\title{
Green Product Purchase Intention: Impact of Knowledge and Green Attitude
}

\section{Minat Pembelian Produk Ramah Lingkungan: Dampak Pengetahuan dan Sikap Berwawasan Lingkungan}

Aang Muhammad Nur Shidiq ${ }^{1}$ and Arry Widodo ${ }^{2}$

1,2Prodi Administrasi Bisnis, Fakultas Komunikasi dan Bisnis, Universitas Telkom

1ªangmuhammad@student.telkomuniversity.ac.id, ${ }^{2}$ arrywie@ telkomuniversity.ac.id

\section{ARTICLE INFO}

\section{Article history:}

Received 6th August 2018

Received in revised form 12th August 2018

Accepted 18th August 2018

\section{Keywords:}

Green Brand Knowledge,

Attitude Toward Green Brand,

Green Product Purchase Intention,

Twin Tulipware

\begin{abstract}
Green products are environmentally sound products, designed and processed in a way to reduce the effects that may pollute the environment, whether in production, distribution and consumption. This study is conducted to determine the effect of green brand knowledge mediated attitudes toward the green brand and how it affects the intention to buy green products manufactured by Twin Tulipware. The purpose of this research is to know and analyze how the green brand knowledge, how the attitude toward the green brand, how the intention to buy green products, the amount of influence knowledge and green attitude to purchase intention of green products manufactured by Twin Tulipware directly and indirectly. The researchers use three research variables categorised as the independent variables and dependent variable. The research method applied in this study is a quantitative inquiry. Sampling is done by nonprobability sampling method with accidental sampling type, with 100 respondents, knowing and using Twin Tulipware product. The data are collected by using questionnaires. The results show that the direct effects of green brand knowledge on the intention to buy green products are $49.5 \%$ and indirect influence through the attitude toward the green brand is $21 \%$. Therefore, the total effect of green brand knowledge on the intention to buy green products through the attitude of the green brand is $70.5 \%$. Knowledge and attitude have a $R 2$ ( $R$ Square) value of $56.6 \%$ of the intention to buy green products.
\end{abstract}

@ 2018 ASMTB PRESS

\section{Pendahuluan}

Tren pasar global saat ini makin mengarah pada produk ramah lingkungan. Ini merupakan peluang yang perlu segera diantisipasi sekaligus dimanfaatkan oleh industri nasional. Saat ini, penggunaan bahan material seperti plastik sudah menjadi bagian keseharian manusia modern. Hal ini turut berkontribusi dalam menggantikan bahan tradisonal seperti kayu, kulit, logam, dan karet. Produksi sampah di Kota Bandung, Kota Cimahi, dan Kabupaten Bandung mencapai 3.950 ton/hari. Sementara kapasitas yang bisa diangkut, hanya 2.750 ton/hari. Hal ini menimbulkan ekses negatif yaitu 
pencemaran lingkungan. Kepala Badan Pengkajian Kebijakan Iklim dan Mutu Industri (BPKIMI), Bapak Arryanto menetapkan bahwa industry ramah lingkungan adalah salah satu tujuan pembangunan industri, hal ini tercantum dalam UU Nomor 3 Tahun 2014 tentang Perindustrian.

Dalam merespon perubahan ini, Twin Tulipware, sebagai salah satu pemasok peralatan ramah lingkungan, menawarkan plasticware dengan beberapa keunggulan praktis yaitu: antipecah, desain yang menawan, ramah lingkungan, dan nuansa warna yang kaya. Meskipun Twin Tulipware telah menawarkan hal ini kepada masyarakat. Respon masyarakat masih kurang. Masih banyak di antara mereka yang menggunakan bahan konvensional yang berpotensi merusak lingkungan. Ketidaksadaran ini, menunjukan kurangnya edukasi pengetahuan terhadap merek dan produk ramah lingkungan beserta dampak yang ditimbulkannya.

Pengetahuan lingkungan menunjukan seberapa besar kesadaran masyarakat tentang lingkungan yang berkaitan dengan tanggung jawab bersama yang diperlukan untuk pembangunan berkelanjutan dan hubungannya yang mengarah pada dampak lingkungan. Penelitian menunjukkan hubungan positif antara pengetahuan lingkungan dan perilaku konsumen. Tingkat pengetahuan konsumen tentang masalah lingkungan menentukan perilaku pembelian mereka dan pengetahuan faktual adalah prasyarat dalam pembentukan sikap. Chan dan Lau menganggap pengetahuan ekologi sebagai prediktor minat pembelian produk ramah lingkungan dan hasil penelitian mereka menunjukkan bahwa orang dengan pengetahuan ekologi yang lebih tinggi di Cina memiliki kemauan kuat untuk membeli ramah lingkungan. Selain itu, dalam sejumlah penelitian, ada hubungan yang signifikan antara pengetahuan lingkungan dan sikap terhadap produk ramah lingkungan yang pada gilirannya memengaruhi minat pembelian produk ramah lingkungan dari para konsumen. Peningkatan minat pembelian berarti peningkatan kemungkinan pembelian (Shah, 2012).

Berdasarkan latar belakang di atas, maka identifikasi masalah dalam penelitian ini adalah bagaimana pengaruh sikap dan pengetahuan produk ramah lingkungan baik secara langsung maupun secara tidak langsung terhadap minat pembelian produk ramah lingkungan. Tujuan dari penelitian ini adalah untuk mengetahui pengaruh sikap dan pengetahuan produk ramah lingkungan baik secara langsung maupun secara tidak langsung terhadap minat pembelian produk ramah lingkungan. Penelitian ini dilaksanakan di kota Bandung pada tahun 2018.

\section{Kajian Literatur}

\section{Green Brand Knowledge}

Green Brand knowledge disebut sebagai "simpul merek produk ramah lingkungan dalam memori konsumen, dengan berbagai asosiasi yang menunjukan komitmen dan kepedulian terhadap lingkungan dan produk ramah lingkungan" (Keller, 1993). Pengetahuan merek ramah lingkungan memberikan informasi tentang sebuah atribut merek produk yang unik dan manfaatnya bagi lingkungan secara keseluruhan bagi konsumen. Selain itu, Engel (Consumer Behavior, 2010) menyatakan bahwa green brand knowledge terbagi menjadi tiga bagian yaitu berkaitan dengan pengetahuan produk (product knowledge), pengetahuan pembelian (purchase knowledge), dan pengetahuan pemakaian (usage knowledge).

1. Pengetahuan produk

kumpulan berbagai macam informasi mengenai produk. Pengetahuan ini meliputi kategori produk, merek, terminologi produk, atribut atau fitur produk, harga produk, dan kepercayaan mengenai produk. Peter \& Olson (2010) menyebutkan bahwa ada tiga jenis tingkat pengetahuan produk yaitu pengetahuan mengenai atribut produk (atribut fisik dan abstrak), pengetahuan mengenai manfaat produk (manfaat fungsional dan psikososial), dan pengetahuan mengenai nilai suatu produk.

2. Pengetahuan pembelian

Pengetahuan pembelian meliputi berbagai informasi yang diproses oleh konsumen untuk memperoleh suatu produk. Pengetahuan pembelian terdiri atas pengetahuan tentang di mana membeli produk dan 
kapan akan membelinya. Keputusan konsumen mengenai tempat pembelian produk akan sangat ditentukan oleh pengetahuannya. Implikasi yang penting bagi strategi pemasaran adalah memberikan informasi kepada konsumen di mana konsumen bisa membeli produk tersebut (Ujang Suwarman, 2011). Hal ini juga menjelaskan informasi seperti di mana membelinya, di mana lokasi pembeliannya, dan kapan akan membelinya.

3. Pengetahuan pemakaian

Bagaimana suatu produk dapat digunakan dan apa yang diperlukan agar benar-benar menggunakan produk tersebut (Engel et.al., 2010). Suatu produk akan memberikan

manfaat kepada konsumen jika produk tersebut telah digunakan atau dikonsumsi oleh konsumen. Informasi akan pemakaian atau penggunaan akan produk menjadi salah satu faktornya. Upaya pemasaran yang dirancang untuk mendidik konsumen tentang bagaimana menggunakan produk pun dibutuhkan (Engel et.al., 2010).

\section{Attitude toward Green Brand}

Menurut (Vermeir \& Verbeke,2007) sikap adalah evaluasi menyeluruh seseorang terhadap suatu objek yang dilihat atau yang dirasakan, yang kemudian memberikan sebuah simpulan mengenai objek tersebut. Sikap adalah konsep penting dalam literatur psikologi lebih dari satu abad, lebih dari 100 definisi dan 500 pengukuran sikap telah dikemukakan oleh para ahli, salah satunya Peter \& Olson (2010) yang menulis “we define attitude as a person's overall evaluation of a concept". menurut Secord dan Backman dalam (Azwar, 2012) "sikap adalah keteraturan tertentu dalam hal perasaan (afeksi), pemikiran (kognisi), dan predisposisi tindakan (konasi) seseorang terhadap sutatu aspek di lingkungan sekitarnya".

Dimensi sikap Menurut Saifuddin Azwar (2012) terdiri dari tiga komponen yang saling menunjang yaitu:

1. Kognitif (pengetahuan/beliefs)

Pengetahuan dan persepsi ini biasanya berbentuk kepercayaan (belief), yaitu konsumen mempercayai bahwa produk memiliki sejumlah atribut. Kognitif ini sering juga disebut sebagai pengetahuan dan kepercayaan konsumen.

2. Afektif (emosional/perasaan)

Afektif berkaitan dengan masalah emosional subjektif seseorang terhadap suatu objek sikap. Secara umum komponen ini disamakan dengan perasaan yang dimiliki objek tertentu.

3. Konatif (tindakan)

Komponen konatif atau komponen perilaku dalam struktur sikap menunjukan perilaku atau kecenderungan berperilaku dengan yang ada dalam diri seseorang berkaitan dengan objek sikap yang dihadapi.

\section{Purchase Intention Green Product}

Niat atau minat membeli produk ramah lingkungan mengacu kepada pribadi konsumen dalam mengkonsumsi produk ramah lingkungan, ketika konsumen mengetahui manfaat produk ramah lingkungan dan memiliki kemauan dalam menjaga lingkungan. Dalam kasus ini sangat mendukung bagi konsumen mengkonsumsi produk ramah lingkungan (Chan, Akehurst, Dagher, \& Itani, 2001, 2012, 2014). Menurut Haryanto \& Chairy dalam (Hizbul, 2007) terdapat tiga jenis intensi yaitu intensi sebagai harapan, intensi sebagai keinginan, dan intensi sebagai rencana.

Menurut Haryanto \& Chairy dalam (Hizbul, 2007), ada tiga jenis intensi yaitu sebagai berikut:

1. Intensi sebagai harapan, yaitu harapan-harapan yang timbul dalam diri seseorang untuk melakukan sesuatu. 
2. Intensi sebagai keinginan, yaitu keinginan dalam diri seseorang untuk melakukan sesuatu.

3. Intensi sebagai rencana, yaitu rencana seseorang untuk melakukan sesuatu.

\section{Green Brand Knowledge with Attitude toward Green Brand}

Green Brand knowledge disebut sebagai "simpul merek ramah lingkungan dalam memori konsumen, dengan berbagai asosiasi yang menunjukan komitmen dan kepedulian terhadap lingkungan dan produk ramah lingkungan" (Keller, 1993). Joalis (2011) menjelaskan bahwa pemasok perlu memberikan penjelasan yang lebih rinci mengenai produk ramah lingkungannya dengan kalimat atau simbol yang menunjukkan 'keramahan' lingkungan. Untuk produk yang ramah lingkungan, pengetahuan merek ramah lingkungan adalah proses untuk memberikan informasi yang mengubah perilaku konsumen menjadi lebih ramah lingkungan (Frank dalam Bhaskaranet et al., 2006). Kepedulian lingkungan secara positif mempengaruhi perilaku terhadap merek ramah lingkungan (Swenson \& Wells dalam Huang et al., 2014).

Iwan (2013) menyatakan bahwa sikap konsumen menjadi faktor yang penting dalam pengambilan keputusan pembelian. Waskito \& Harsono (2012) dalam penelitiannya di masyarakat Joglosemar mendemonstrasikan bahwa pengetahuan terhadap lingkungan, dan kegiatan berpolitik berpengaruh secara signifikan terhadap semua perilaku pembelian masyarakat pada produk ramah lingkungan, baik perilaku pembelian secara umum maupun produk ramah lingkungan yang memiliki penekanan khusus. Kemudian, Wahyuni (2005) juga menjelaskan bahwa terdapat hubungan positif pengetahuan dan sikap mahasiswa terhadap lingkungan hidup, makin tinggi pengetahuan lingkungan maka sikap terhadap lingkungan juga semakin tinggi.

\section{Attitude toward Green Brand with Purchase Intention Green Product}

Sikap adalah keadaan mental yang kompleks dan abadi yang melibatkan keyakinan, perasaan, nilainilai, dan disposisi untuk bertindak dengan cara-cara tertentu dalam penilaian keseluruhan hal-hal. Dari perspektif pemasaran, sikap konsumen adalah faktor yang berpengaruh langsung terhadap niat pembelian mereka (Solomon, 2009; Ajzen \& Fishbein, 1980).

Beberapa peneliti (Chan, 2001; Kim, 2011; Mostafa, 2009) telah mengungkap peran dari sikap terhadap konsumsi produk ramah lingkungan. Chan (2001) meneliti faktor-faktor penentu sikap yang mengarah ke perilaku konsumen pembelian produk ramah lingkungan, salah satu variabel yang termasuk dalam penelitiannya adalah orientasi alami. Penelitian menegaskan peran penting dari sikap dalam studi perilaku konsumen produk hijau. (Kim, 2011) mencoba memahami pola konsumsi produk ramah lingkungan dengan menyelidiki peran kolektivisme, nilai-nilai pribadi, sikap lingkungan dan persepsi konsumen yang efektif. Mostafa (2009) menunjukkan bahwa konsumen dengan sikap positif terhadap produk ramah lingkungan mempunyai predisposisi yang lebih kuat untuk membeli produk ramah lingkungan dan mereka sangat bergantung pada posisi produk yang bermerek ramah lingkungan. Lebih jauh, sikap akan berdampak pada niat pembelian produk ramah lingkungan, sesuai dengan penelitian yang membuktikan bahwa sikap berpengaruh positif terhadap niat beli produk hijau atau produk ramah lingkungan.

Green Brand Knowledge with Attitude toward Green Brand and Purchase Intention Green Product Citra positif adalah dasar yang membentuk sikap para pelanggan dan salah satu hal yang memengaruhi niat mereka untuk membeli produk ramah lingkungan (Schiffman \& Wisenblit, 2014). Konsumen adalah pihak yang harus menerima informasi tentang isu lingkungan dan produk ramah lingkungan. Mereka juga harus diberi pemahaman tentang merek ramah lingkungan dan difasilitasi dalam proses pembelian produk ramah lingkungan (Ganapathy, Geyer-Alley \& Zacarias-Farah, Thongplew, 2014, 2003, 2014). Edukasi merek ramah lingkungan adalah proses memberikan informasi yang mengubah perilaku konsumen menjadi lebih ramah lingkungan (Frank dalam 
Bhaskaranet, 2006). Kepedulian lingkungan secara positif mempengaruhi perilaku terhadap merek ramah lingkungan (Swenson \& Wells dalam Huang, 2014). Teng (2009) mengemukakan bahwa konsumen dengan sikap positif terhadap merek tertentu cenderung memiliki niat membeli yang lebih kuat untuk membeli merek tersebut. Riset dalam green marketing telah mencatat bahwa sikap positif konsumen terhadap produk ramah lingkungan dapat mempengaruhi niat pembelian mereka (Chang \& Wu, Laroche, 2001, 2015).

\section{Framework}

Berdasarkan rumusan masalah dan teori yang dipaparkan di kajian literatur, maka dirumuskanlah empat hipotesis sebagai berikut:

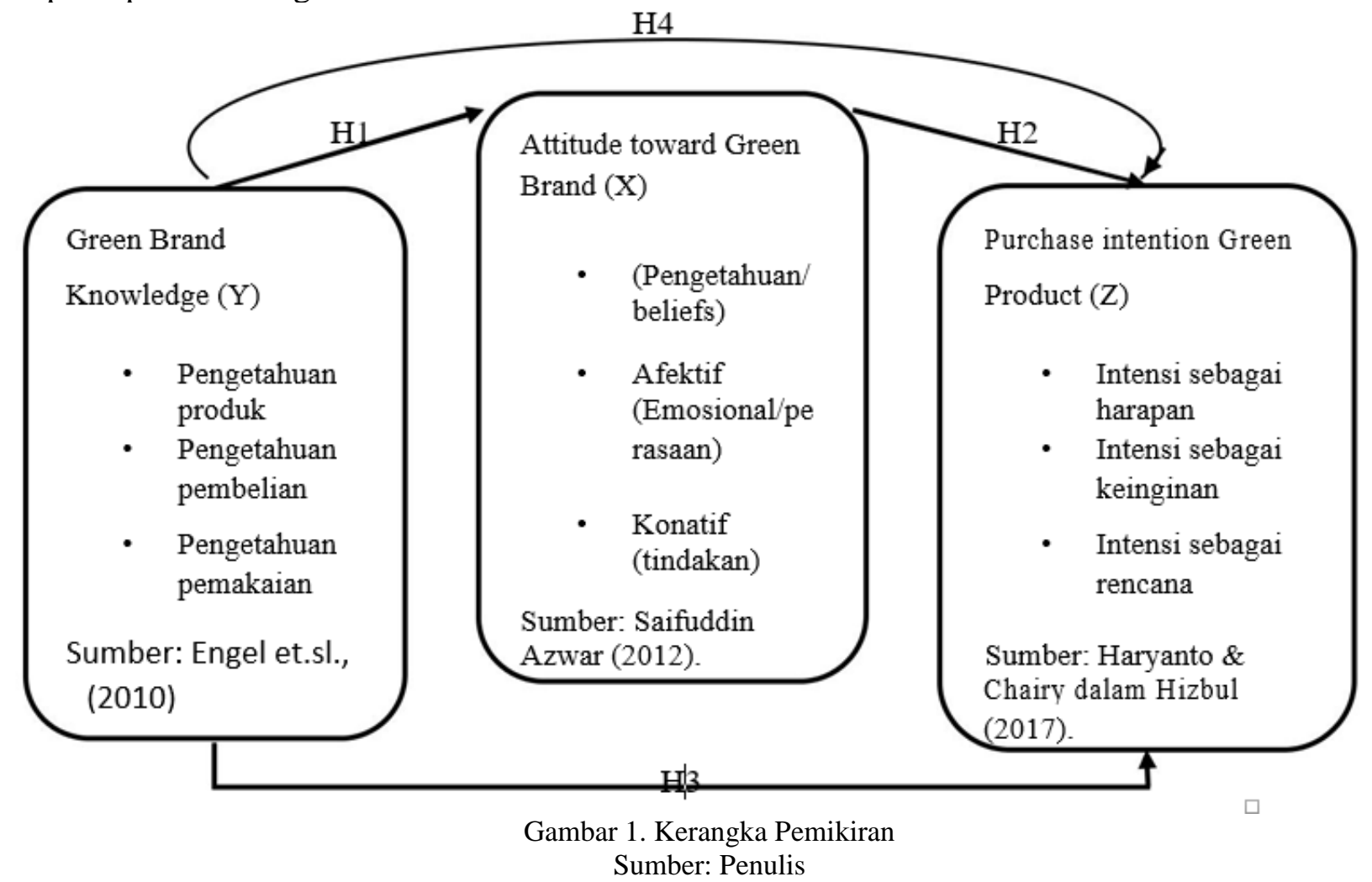

Hipotesis 1: Pengetahuan merek ramah lingkungan memiliki pengaruh terhadap sikap pada merek ramah lingkungan.

Hipotesis 2: $\quad$ Sikap pada merek ramah lingkungan memiliki pengaruh terhadap niat beli produk ramah lingkungan.

Hipotesis 3: Pengetahuan merek ramah lingkungan memiliki pengaruh terhadap niat beli produk ramah lingkungan.

Hipotesis 4: Pengetahuan merek ramah lingkungan yang dimediasi oleh sikap pada merek ramah lingkungan memiliki pengaruh terhadap niat beli produk ramah lingkungan. 


\section{Metode Penelitian}

Desain penelitian yang digunakan adalah analisis deskriptif. Jenis penelitian yang dilakukan adalah penelitian kuantitatif yang diperangkati dengan prosedur statistic atau cara lain dari kuantifikasi atau pengukuran (Sujarweni, 2015). Skala instrumen yang digunakan untuk mengukur variabel operasional dalam penelitian ini adalah likert. Sugiyono, (2015) menyatakan bahwa skala likert digunakan untuk mengembangkan instrumen yang digunakan untuk mengukur sikap, persepsi, dan pendapat seseorang atau kelompok orang terhadap potensi dan permasalahan suatu objek, rancangan suatu produk, proses membuat produk dan produk yang telah dikembangkan atau diciptakan. Pembobotan nilai jawaban dalam penelitian ini berskala 1 sampai 5.

Populasi yang dilibatkan dalam penelitian ini adalah seluruh pengguna plasticware atau lebih khususnya container tempat makanan dan botol minum atau tumbler di kota Bandung yang jumlahnya tidak diketahui secara pasti. Untuk menentukan jumlah sampel dari populasi yang tidak diketahui secara pasti, penelitian ini menggunakan rumus Bernoulli sehingga diperoleh angka 96,04 untuk jumlah sampel minimum, tetapi penulis membulatkannya menjadi 100 responden untuk mengurangi kesalahan dalam pengisian kuesioner.

Teknis analisis data yang dipakai adalah analisis deskriptif dan SEM menggunakan bantuan software SmartPLS. Statistik deskriptif hanya menguraikan atau memberikan keterangan mengenai suatu data dan fenomena. Ghozali, (2015) menyatakan bahwa metode SEM merupakan suatu metode yang menghubungkan analisis regresi, analisis jalur (path analysis) dan analisis faktor.

\section{Hasil dan Diskusi}

\section{Analisis Deskriptif}

Hasil analisis menunjukkan bahwa pengetahuan merek ramah lingkungan mendapat tanggapan responden sebesar 1924 atau 77,0\% dari skor ideal 2500. Hasil tersebut, termasuk kategori baik. Variabel sikap pada merek ramah lingkungan mendapat tanggapan dari responden sebesar 1870 atau $74,8 \%$ dari skor ideal 2500. Hasil tersebut termasuk kategori baik. Kemudian, niat beli produk ramah lingkungan mendapat tanggapan dari responden sebesar 1172 atau 78,1\% dari skor ideal 1500. Hasil tersebut termasuk kategori baik.

Dalam structural equation modeling ada dua jenis model yang terbentuk, yaitu model pengukuran dan model struktural. Model pengukuran menjelaskan proporsi variance masing-masing variabel manifest (indikator) yang dapat dijelaskan di dalam variabel laten. Berdasarkan metode estimasi first order dari Partial Least Square diperoleh diagram jalur full model seperti terlihat pada gambar berikut: 


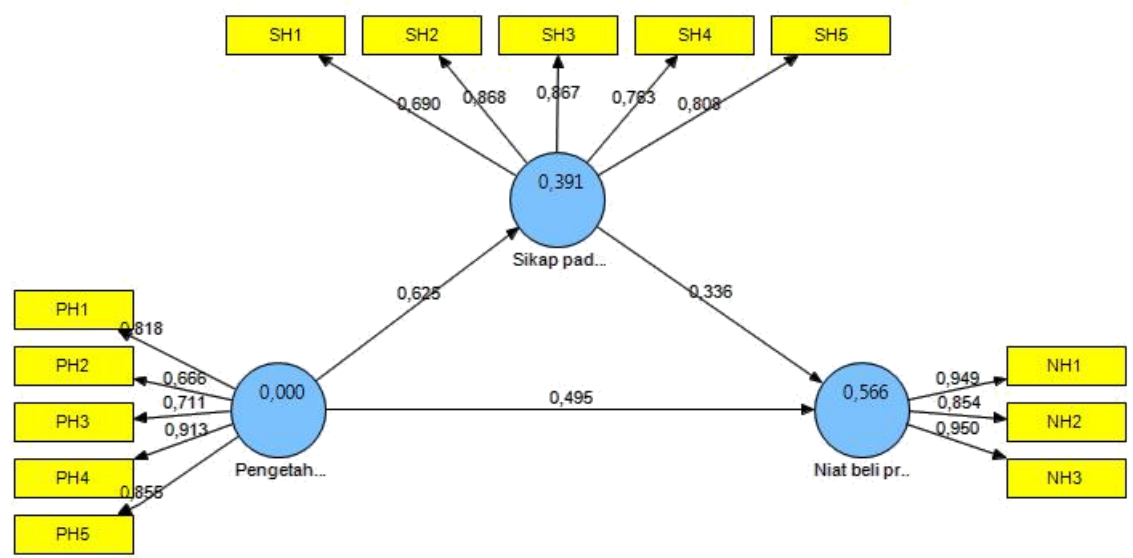

Gambar 2.

Diagram Jalur Full Model Struktural

Sumber: Hasil Output SmartPLS

Melalui loading faktor yang terdapat pada gambar di atas selanjutnya dapat diketahui validitas dari masing-masing indikator serta menguji reliabilitas dari konstruk variabel yang diteliti. Seperti pada tabel uji validitas konvergen di bawah:

Tabel 1. Uji Validitas Konvergen

\begin{tabular}{|c|c|c|c|c|c|}
\hline Variabel & Indikator & $\begin{array}{c}\text { Loading } \\
\text { Faktor } \\
>0.5\end{array}$ & $\begin{array}{c}\mathrm{t} \\
\text { statistic } \\
>1.96\end{array}$ & $\begin{array}{l}\text { AVE } \\
>0.5\end{array}$ & $\begin{array}{l}\text { CR } \\
>0.7\end{array}$ \\
\hline \multirow{5}{*}{$\begin{array}{l}\text { Pengetahuan } \\
\text { merek ramah } \\
\text { lingkungan }\end{array}$} & PH1 & 0,818 & 21,844 & \multirow[t]{5}{*}{0,637} & \multirow[t]{5}{*}{0,896} \\
\hline & $\mathrm{PH} 2$ & 0,666 & 8,804 & & \\
\hline & PH3 & 0,711 & 12,752 & & \\
\hline & $\overline{\mathrm{PH}} 4$ & 0,913 & 58,698 & & \\
\hline & PH5 & 0,855 & 32,206 & & \\
\hline \multirow{3}{*}{$\begin{array}{l}\text { Sikap pada merek } \\
\text { Ramah lingkungan }\end{array}$} & SH1 & 0,690 & 12,585 & \multirow[t]{2}{*}{0,643} & \multirow[t]{4}{*}{0,899} \\
\hline & $\begin{array}{l}\mathrm{SH} 2 \\
\mathrm{SH} 3 \\
\mathrm{SH} 4 \\
\mathrm{SH} 5\end{array}$ & $\begin{array}{l}0,868 \\
0,867 \\
0,763 \\
0,808\end{array}$ & $\begin{array}{l}32,547 \\
36,390 \\
15,386 \\
26,097\end{array}$ & & \\
\hline & $\begin{array}{c}\mathrm{NH} 1 \\
\mathrm{NH} 2\end{array}$ & $\begin{array}{c}0,949 \\
0,854\end{array}$ & $\begin{array}{c}87,136 \\
37,931\end{array}$ & 0,844 & \\
\hline Ramah lingkungan & $\mathrm{NH} 3$ & 0,950 & 90,601 & & \\
\hline
\end{tabular}

Sumber: Hasil ouput smart PIS 
Berdasarkan hasil pengolahan yang disajikan pada tabel di atas dapat diketahui bahwa semua indikator memiliki loading faktor lebih besar dari 5 sehingga valid. Artinya, semua indikator sudah valid dalam mengukur masing-masing variabel latennya. Selain itu, semua variabel laten memiliki nilai AVE di atas 0,5 dan CR di atas 0,7 sehingga reliabel.

Pengujian validitas diskriminan dengan cara membandingkan nilai akar ave dengan korelasi antarvariabel laten.

Tabel 2. Uji Validitas Diskriminan

\begin{tabular}{|c|c|c|c|}
\hline & Niat beli produk & $\begin{array}{c}\text { Pengetahuan } \\
\text { merek ramah } \\
\text { lingkungan }\end{array}$ & $\begin{array}{c}\text { Sikap pada } \\
\text { merek ramah } \\
\text { lingkungan }\end{array}$ \\
\hline \hline $\begin{array}{c}\text { Niat beli produk ramah } \\
\text { lingkungan }\end{array}$ & 0,919 & & \\
\hline \hline $\begin{array}{c}\text { Pengetahuan merek ramah } \\
\text { lingkungan }\end{array}$ & 0,705 & 0,798 & \\
\hline $\begin{array}{c}\text { Sikap pada merek ramah } \\
\text { lingkungan }\end{array}$ & 0,645 & 0,625 & 0,802 \\
\hline
\end{tabular}

Catatan: nilai yang ditandai tebal merupakan nilai akar AVE

Dari tabel di atas terlihat bahwa nilai akar AVE dari masing-masing variabel latennya lebih tinggi dibandingkan nilai korelasi tertinggi di variabel tersebut sehingga dapat disimpulkan bahwa model memiliki validitas diskriminan yang baik.

Model struktural adalah model yang menghubungkan variabel laten eksogen dengan variabel laten endogen atau hubungan variabel endogen dengan variabel endogen lainnya. Berdasarkan pengujian bootstraping diperoleh hasil full model struktural sebagai berikut:

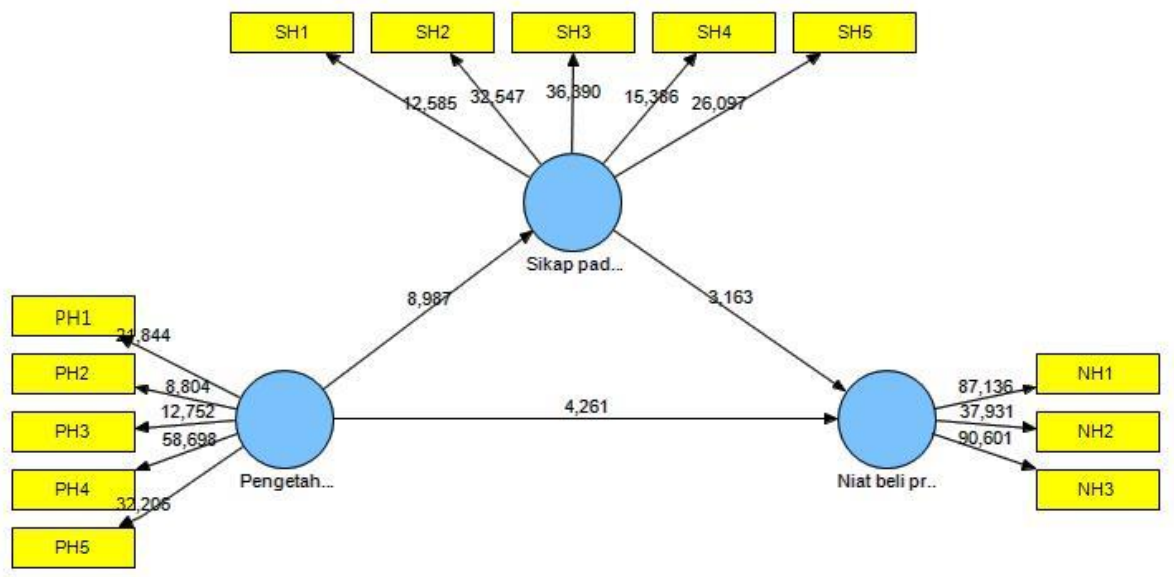

Gambar 3.

Diagram Jalur Full Model Struktural (Bootstraping)

Sumber: Hasil Output SmartPLS 
Tabel 3. Rangkuman hasil uji statistik

\begin{tabular}{|l|l|l|l|}
\hline Hubungan & \multicolumn{1}{|c|}{ Path } & $\begin{array}{c}\text { t } \\
\text { statistik }\end{array}$ & \multicolumn{1}{|c|}{ R Square } \\
\hline $\begin{array}{l}\text { Pengetahuan merek ramah } \\
\text { lingkungan } \\
\text { Sikap pada merek ramah lingkungan }\end{array}$ & 0,625 & 8,987 & 0,391 \\
\hline $\begin{array}{l}\text { Pengetahuan merek ramah } \\
\text { lingkungan } \\
\text { Niat beli produk ramah lingkungan }\end{array}$ & 0,495 & 4,261 & \\
\cline { 1 - 3 } $\begin{array}{l}\text { Sikap pada merek ramah lingkungan -> Niat } \\
\text { beli produk ramah lingkungan }\end{array}$ & 0,336 & 3,163 & 0,566 \\
\hline
\end{tabular}

$*_{\text {kritis }}=1,96$

Sumber: Hasil output SmartPLS

Melalui nilai koefisien determinasi ( $R$-square) yang terdapat pada tabel di atas dapat diketahui bahwa pengetahuan merek ramah lingkungan memberikan pengaruh sebesar 39,1\% terhadap sikap pada merek ramah lingkungan. Kemudian, pengetahuan merek ramah lingkungan dan sikap pada merek ramah lingkungan secara simultan memberikan pengaruh sebesar 56,6\% terhadap niat beli produk hijau. Melalui pengujian hipotesis, dinyatakan bahwa:

1. Pengetahuan merek ramah lingkungan berpengaruh signifikan terhadap sikap pada merek ramah lingkungan. Artinya, pengetahuan merek ramah lingkungan dengan sikap pada merek ramah lingkungan memiliki hubungan searah semakin tinggi pengetahuan merek ramah lingkungan maka akan meningkatkan sikap pada merek ramah lingkungan.

2. Sikap pada merek ramah lingkungan berpengaruh signifikan terhadap niat beli produk ramah lingkungan. Sikap pada merek ramah lingkungan dengan niat beli produk ramah lingkungan memiliki hubungan searah semakin tinggi sikap pada merek ramah lingkungan maka akan meningkatkan niat beli produk ramah lingkungan.

3. Pengetahuan merek ramah lingkungan berpengaruh signifikan terhadap niat beli produk ramah lingkungan. Pengetahuan merek ramah lingkungan dengan niat beli produk ramah lingkungan memiliki hubungan searah semakin tinggi pengetahuan merek ramah lingkungan maka akan meningkatkan niat beli produk ramah lingkungan.

4. Pengetahuan merek ramah lingkungan dan sikap pada merek ramah lingkungan secara simultan berpengaruh signifikan terhadap niat beli produk ramah lingkungan.

Tabel 4. Pengaruh tidak langsung

\begin{tabular}{|l|c|c|c|}
\hline \multicolumn{1}{|c|}{ Hubungan } & $\begin{array}{c}\text { Pengaruh } \\
\text { Langsung }\end{array}$ & $\begin{array}{c}\text { Pengaruh } \\
\text { Tidak } \\
\text { Langsung }\end{array}$ & $\begin{array}{c}\text { Pengaruh } \\
\text { Total }\end{array}$ \\
\hline $\begin{array}{l}\text { Pengetahuan merek ramah } \\
\text { lingkungan } \\
\begin{array}{l}\text {-> Sikap pada merek ramah } \\
\text { lingkungan }\end{array}\end{array}$ & 0.625 & - & 0.625 \\
\hline
\end{tabular}




\begin{tabular}{|l|c|c|c|}
$\begin{array}{l}\text { Pengetahuan merek ramah } \\
\text { lingkungan } \\
\begin{array}{l}\text {-> Niat beli produk ramah } \\
\text { lingkungan }\end{array}\end{array}$ & 0.495 & 0.210 & 0.705 \\
\hline $\begin{array}{l}\text { Sikap pada merek ramah } \\
\text { lingkungan -> } \\
\text { Niat beli produk ramah } \\
\text { lingkungan }\end{array}$ & 0.336 & - & 0.336 \\
\hline
\end{tabular}

Sumber: Hasil output SmartPLS

Pengaruh langsung pengetahuan merek ramah lingkungan terhadap niat beli produk ramah lingkungan adalah 0.495 dan pengaruh tidak langsung melalui sikap pada merek ramah lingkungan adalah 0.210. Sehingga total pengaruh pengetahuan merek ramah lingkungan terhadap niat beli produk ramah lingkungan melalui sikap pada merek ramah lingkungan sebesar 0.705. Sedangkan, pengaruh sikap pada merek ramah lingkungan terhadap niat beli produk ramah lingkungan adalah 0.336. dari hasil tersebut bisa dinyatakan bahwa H0 ditolak. Hal ini berarti sikap pada merek ramah lingkungan berpengaruh signifikan bisa menjadi mediasi antara pengetahuan merek ramah lingkungan terhadap niat beli produk ramah lingkungan.

\section{Simpulan}

Simpulan yang diperoleh dalam penelitian ini adalah sebagai berikut:

1. Variabel pengetahuan merek ramah lingkungan pada produk Twin Tulipware berada pada kategori baik. Dengan total skor 1924 atau 77,0\% dari skor ideal 2500.

2. Variabel sikap pada merek ramah lingkungan pada produk Twin Tulipware berada pada kategori baik. Dengan total skor atau 74,8\% dari skor ideal 2500.

3. Variabel niat beli produk ramah lingkungan pada produk Twin Tulipware berada pada kategori baik. Dengan total skor adalah 1172 atau 78,1\% dari skor ideal 1500.

4. Pengetahuan secara langsung memiliki pengaruh sebesar $49.5 \%$ terhadap niat beli produk ramah lingkungan dan memiliki pengaruh tidak langsung sebesar $21 \%$ dengan melalui sikap pada merek ramah lingkungan. Sehingga pengaruh totalnya sebesar $70.5 \%$. Artinya sikap pada merek ramah lingkungan memiliki pengaruh sebagai mediasi dan bisa menjadi mediasi yang baik.

5. Pengetahuan dan sikap memiliki nilai $\mathrm{R}^{2}$ ( $\mathrm{R}$ Square) sebesar 56,6\% terhadap niat beli produk ramah lingkungan.

Saran untuk penelitian selanjutnya:

1. Melakukan penelitian dengan menambahkan variable reputasi perusahaan, brand image, kinerja, ataupun kepercayaan.

2. Penelitian selanjutnya dapat menggunakan variabel yang sama namun dapat mencoba untuk meneliti objek penelitian yang berbeda.

3. Penelitian selanjutnya dapat menggunakan software bantuan yang berbeda selain SmartPLS, misalnya seperti, SPSS, Lisrel, ataupun AMOS. 


\section{Referensi}

Abdillah, Willy, Hartono, \& Jogiyanto. (2015). Partial Least Square (PLS) Alternatif Structural Equation Modeling (SEM) dalam Penelitian Bisnis. Yogyakarta: C.V Andi Offset.

Achmad, Aniesa, Fauzi, Bafadhal, \& Samira. (2018). Pengaruh Green Product, Green Advertaising dan Green Brand Terhadap Keputusan Pembelian (Survei pada konsumen Air minum kemasan merek ADES).

Administrator. (2018, Maret). Retrieved from Kebijakan Pengembangan Industri Hijau (Green Industry) Kementerian Perindustrian: http://greenlistingindonesia.com/berita-147kebijakan-pengembangan-industri-hijau-green-industry-kementerian-perindustrian.html

Ajzen, \& Fishbein, M. (1980). Understanding Attitudes an Predicting Social Behavior. PrenticeHall, Englewood Cliffs, New Jersey.

Alba, \& Hutchinson. ((1987)).

Alma, \& Buchari. (2011). Manajemen Pemasaran dan Pemasaran Jasa. Bandung: Alfabeta.

Arnould, P. \&. (2005). Consumers (2 ed.). McGraw - Hill.

Aulina, L., \& Yuliati, E. (2017). The Effects of Green Brand Positioning, Green Brand. Atlantis Press, 36, 550.

Azmi, \& Shalahudin, M. (2016). Pengaruh Green Product, Green Advertaising, and Green Brand terhadap Keputusan Pembelian Lampu LED Philips (Studi kasus pada konsumen lampu LED Philips di Kecamatan Minggir, Kabupaten Sleman).

Azwar, S. (2012). Sikap Manusia: Teori dan Pengukurannya. Yogyakarta: Liberty.

Chan, R. (2001). Determinants of Chinese Consumers Green Purchasing Behaviour. Psychology and Marketing, 18(4).

Chang, M., \& Wu, C. (2015). The Effect of Message Framing on Pro-Environmental Behavior Intentions: an Information Processing View. Bristish Food Journal, 117(1).

Chen, Shan, Y., Chang, \& ChingHsun. (2012). Enhance Green Purchase Intention: The Roles of Green Perceived Value, Green Perceived Risk, and Green Trust.

Connell, K. (2010). Internal and External Barriers to Eco-Conscious Apparel Acquisition. International Journal of Consumer Studies, 34(3).

Daryanto. (2011). Manajemen Pemasaran: Sari Kuliah. Bandung: Satu Nusa.

Dewi, I., \& Antawati, D. (2018, Maret). Retrieved from Parent Role in Promoting Children's Entrepreneurship Intention: https://www.researchgate.net/figure/Fishbein-AjzensTheory-of-Planned-Behavior_fig1_313055840

Engel, J. e. (1994). Consumer Behavior (1 ed.). Jakarta: Erlangga, Binarupa Aksara. 
Ganapathy, S., Natarjan, J., Gunasekaran, A., \& Subramanian, N. (2014). Influence of EcoInnovation on Indian Manufacturing Sector Sustainable Performance. International Journal of Sustainable Development and World Ecology, 21(3).

Gayer-Allely, E., \& Zacarias-Farah, A. (2003). Policies and Instruments for Promoting Sustanable Household Consumption. Journal of Cleaner Production.

Gill, A., \& Shah, C. (2012). Determinants of Corporate Cash Holdings: Evidence from Canada. International Journal of Economics and Finance, 4(1).

Hartamann, P., \& Ibanez, V. (2006). Green Value Added. Marketing Intelligence an Planning.

Hasan. (2013). Marketing dan Kasus-Kasus Pilihan. Yogyakarta: Center For Academic Publishing Service.

Hasibuan, M. S. (2011). MANAJEMEN: Dasar, Pengertian, dan Masalah. Jakarta: PT Aksara.

Huang, Y.-C., Yang, M., \& Wang, Y.-C. (2014). Effects of Green Brand on Green Purchase Intention. Emeraldinsight, 32(3).

Kasali, R. (2005). Manajemen Public Relations Konsep dan Aplikasinya di Indonesia. Jakarta: PT Pustaka Utama Grafari.

Keller, K. (1993). Conceptualizing, Measuring, and Maganing Customer-Based Brand Equity. Journal of Marketing.

Kinnear, L. T., \& Taylor. (1996). Marketing Research (5 ed.). New York: Mc Graw Hill.

Kotler, \& Keller. (2009). Manajemen Pemasaran (13 ed.). Jakarta: Erlangga.

Kotler, P. \&. (2014). Principle Of Marketing (15 ed.). New Jersey: Pearson Prentice Hall.

Kotler, Philip, \& Keller. (2016). Marketing Management (15 ed.). Person Prencite Hall, inc.

Kotler, Philip, Amstrong, \& Gary. (2016). Principle of Marketing (15 ed.). Person Prencite Hall, inc.

Kusumawati, \& Dita. (2015). Pengaruh Green Product, Atribut Produk dan Word of Mouth Terhadap Keputusan Pembelian (Studi kasus pada konsumen Produk Tupperware Mahasiswa Strata 1 Fakultas Ekonomi Universitas Negeri Yogyakarta).

Mostafa, M. (2009). Shades of Green: A Psychographic Segmentation of the Green Consumer in Kuwait Using Selg-Organizing Maps. Expert Systems with Applications.

Mourad, Maha, \& Yasser, A. S. (2012). Perception of Green Brand in an Emerging Innovative Market. European Journal of Innovation Management, 15(4).

Nugraha, \& Eko, W. (2002). Penelitian Organik Sebagai Alternatif teknologi dalam upaya menghasilkan Produk Hijau. Retrieved from www.google.com.

Ottman, J., \& Reilly, R. W. (1998). Green marketing; Opportunity for innovation. (4 ed.). Jakarta: Erlangga. 
Peter, P. J., \& Olson, J. (2013). Perilaku Konsumen dan Strategi Pemasaran (9 ed.). Jakarta: Salemba Empat.

Pixaal. (2018, Maret). Retrieved from Twin Tulipware: http://twintulipware.com/

Prasetijo, \& Ihalauw. (2005). Perilaku Konsaumen. Yogyakarta: Andi Offset.

Rennings, K. (2000)). Refending Innovation - Eco-innovation Research and the Contribution from Ecological Economics. . Ecological Economics, 32, 319-332.

Ridwan, M., D.H, A. F., \& Bafadhal, A. S. (2018). Pengaruh Green Product, Green Advertaising dan Green Brand. Jurnal Administrasi Bisnis (JAB), 55(1), 84.

Rivai, V. \&. (2010). Manajemen Sumber Daya Manusia untuk perusahaan. Jakarta: PT Raja Grafindo Persada.

Sangadji, Etta, M., \& Sopiah. (2013). Perilaku Konsumen-Pendekatan Praktis disertai Himpunan Jurnal Penelitian. Yogyakarta: ANDI.

Schiffman, G. L., \& Kanuk, L. L. (2007). Consumer Behavior Tent.

Schiffman, L., \& Wisenblit, J. (2014). Consumer Behaviour. Pearson Education inc., New Jersey.

Shabani, \& Nazanin. (2013). The Study of Green Consumers Characteristic and Available Green Sectors in the Market. International Research Jurnal of Applied and Basic Sciences, 4(7).

Shabani, N. M. (2013). The Study of Green Consumers' Characteristics and Available Green Sectors in The Market. International Research Journal of Applied and Basic Science.

Spears, N., \& Singh, N. S. (2004)). Measure attitude toward the brand and purchase intentions. Journal of Current Issues and Research in Advertising, 26(2).

Sugiyono. (2012). Metode Penelitian Kuantitatif, Kualitatif dan R\&D. Bandung: Alfabeta.

Sugiyono. (2013). Statistika untuk Penelitian. Bandung: Alfabeta.

sujarweni, \& wiratna. (2015). Metodologi Penelitian Bisnis dan Ekonomi. Yogyakarta: Pustaka Baru.

Suki, N. M. (2016). Green Product Purchase Intention: Impact of Green Brands, Attitude, and Knowledge. Emeraldinsight, 118(12).

Sumarwan, U. (2015). Perilaku Konsumen Teori dan Penerapannya dalam Pemasaran (kedua ed.). Bogor: Ghalia Indonesia.

Suparyanto, \& Rosad. (2015). Manajemen Pemasaran. Bogor: In Media.

Suwarso, N. H., \& K, N. M. (2015). Pengaruh Pengetahuan dan Sikap Terhadap Niat Beli. EJurnal Manajemen Unud, 4(10).

Swenson, M. (1997). Duke’s Physiology of Domestic Animal. Comstock. Ithaca New York: Co. Inc. 
Teng. (2009). A Comparison of Two Types of Price Discount in Shifting Consumers Attitude and Purchase Intentions. Journal of Business Research.

Thogersen, J., Dutra, M. d., Perin, G., \& Zhou, Y. (2015). Consumers Buyiong Motives and Attitudes towards Organic Food in Two Emerging Markets. International Marketing Review.

Vilčeková, L., \& Sabo, M. (2013). The Influence of Demographic Factors on Attitudes toward Brands and Brand. International Journal of Education and Research, 1(11).

Wagner, Peter, Lang, \& Gerhard, K. (2006). Lacrimal System (Ophthalmology ed.). New York.

Waskintro, J., \& M, H. (2012). Pengembangan dan Implementasi model strategi pemasaran berwawasan lingkungan: Studi empiris pada masyarakat. joglosemar, 33-39.

Widelia, K., Yusiana, R., \& Widodo, A. (2015). Pengaruh Green Marketing dan Corporate Social Responsibility terhadap Keputusan Pembelian Produk Unilever (Studi Kasus Masyarakat Kota Bandung). Jurnal Ecodemica: Jurnal Ekonomi, Manajemen, dan Bisnis, 3(2), 541.

Widodo, A., Yusiana, R., \& Stevanie, C. (2015). Pengaruh Green Marketing Terhadap Nilai yang dipesepsikan Dalam Keputusan Pembelian Pada Ades (Studi Kasus Pada Mahasiswa/i Fakultas Komunikasi dan Bisnis Telkom University). Jurnal Ecodemica: Jurnal Ekonomi, Manajemen, dan Bisnis, 2(3), 530.

Wolsink, M. (2007). Wind Power Implemantation: The Nature of Public Attitudes: Equity and Fairness Instead of "Backyard Motives". Renewable and Sustainable Energy Reviews.

Yadav, R. a. (2016). Young Consumers Intention towards Buying Green Products in a Developing Nation: Extending the Theory of Planned Behaviour. Journal of Clieaner Production. 